ГРНТИ 21., 21.21

\author{
"Talasbayev Sh.A., Borbassova K.M. \\ Al-Farabi Kazakh national university, Kazakhstan, Almaty \\ *e-mail:Shalkar.sb94@gmail.com
}

\title{
THE INTERNET AND RELIGIOUS COMMUNICATION IN KAZAKHSTAN
}

Religious organizations of Kazakhstan are actively developing the Internet to create their information and communication space. Today, the Internet has become not only a platform for interreligious dialogue, a missionary field of traditional religions, but also a way of spreading various quasi-religious ideas. Today the Internet is the main information channel, where news about religious life in Kazakhstan appears and circulates. The Internet is a free environment, practically unrestricted by the ideological and formal framework that operates in the "big media", in addition, other commercial schemes operate here. Therefore, the spectrum of topics artificially narrowed in the modern media mainstream (print media, radio and television), looks much wider here. The article analyzes the content of religious topics on Kazakh sites. The features of religious currents in the territory of the Republic of Kazakhstan and the areas of their distribution are analyzed. Attention is drawn to the great influence of the media on the development of religious organizations and the dissemination of information. The conclusion is made about the increase in awareness and religious activity in connection with the growth of the dissemination of information of religious content.

Keywords: religion, Islam, discourse, website, sect, Internet space Internet, Internet community, "second religious identity", religious community, traditional religions on the web, New Age movement.

*Таласбаев Ш.А., Борбасова К.М.

Казахский национальный университет имени аль-Фрааби, Республика Казахстан, г. Алматы *e-mail:Shalkar.sb94@gmail.com

Интернет и религиозные коммуникации в Казахстане

Религиозные организации Казахстана активно осваивают интернет Аля создания своего информационного и коммуникационного пространства. Сегодня интернет стал не только площаАкой межрелигиозного диалога, миссионерским полем традиционных религий, но также способом распространения различных квазирелигиозных идей. Сегодня интернет - основной информационный канал, гАе появ^яются и циркулируют новости о религиозной жизни в Казахстане. Интернет - это свободная среда, практически не стесненная идеологическими и формальными рамками, которые действуют в «больших СМИ», кроме того, зАесь Аействуют Аругие коммерческие схемы. Поэтому спектр тем, искусственным образом суженный в современном медийном мэйнстриме (печатных изданиях, на радио и телевидении), здесь выглядит значительно шире. В статье анализируется содержание религиозных тем на казахских сайтах. Проанализированы особенности религиозных течений на территории Республики Казахстан и ареалы их распространения. Обращается внимание на большое влияние среАств массовой информации на развитие религиозных организаций и распространение ими информации. САелан вывод о повышении роста информированности и религиозной активности в связи с нарастанием темпов распространения информации ремигиозного содержания.

Кмючевые слова: религия, ислам, Аискурс, сайт, секта, интернет-пространство интернет, интернет-сообщество, «вторая религиозная идентичность», религиозное сообщество, традиционные религии в Сети, движение New Age. 
Talasbayev Sh.A., Borbassova K.M.

\author{
*Таласбаев Ш.А., Борбасова К.М. \\ Ә^-Фараби атындағы Қазақ ұлттық университеті, Қазақстан Республикасы, Алматы қ. \\ *e-mail:Shalkar.sb94@gmail.com
}

\title{
Қазақстандағы ғамамтор және діни коммуникациялар
}

\begin{abstract}
Қазақстанның діни бірлестіктері ақпараттық-коммуникациямық кеңістікті құру үшін ғаламторды белсенді түрде дамытуда. Бүгінгі таңда ғаламтор дінаралық үнқатысу алаңына, дәстүрлі діндердің миссионерлік саласына ғана емес, сондай-ақ әртүрлі квази-діни идеяларды тарату тәсіліне айналды. Бүгінде Ғаламторда Қазақстандағы діни өмір туралы жаңалықтар пайда болатын және айналымға түсетін негізгі ақпараттық арна болып табылады. Ғаламтор - бұл «үлкен медиада» жұмыс істейтін идеологиялық және формальды негіздермен шектелмейтін еркін орта, сонымен қатар мұнда басқа коммерциялық схемалар жұмыс істейді. Сондықтан, заманауи БАҚтарда (баспа, радио және теледидар) жасанды түрде таралған тақырыптардың кең спектрі осы жерде кеңірек көрінеді. Мақалада қазақстандық сайттардаға діни ақпараттар анализден өткен. Қазақстан Республикасының аумағында таралған Аіни ағымдардың ерекшеліктері сараланып, олардың таралған аумақтарыс қарастырылған. Басты назар БАҚ ақпараттары және оның Аіни ұйымдардың ақпараттарды таратуы және әсеріне бағытталған. Аіни мазмұндағы ақпараттың таралуының өсуіне байланысты діни хабардарлықтың және Аіни қызметтің өсуі туралы қорытынАы жаса^ды.

Түйін сөздер: Аін, ислам, Аискурс, сайт, секта, ғаламтор-кеңістігі, ғаламтор, ғаламторқоғамдастығы, «екінші діни сәйкестік», діни қауым, ғаламтордағы дәстүрлі діндер, New Age қозғалысы.
\end{abstract}

\section{Introduction}

Religious organizations use various channels of mass communication with missionary purposes, as well as to maintain the integrity of the religious community and its development, to ensure the intensity of information exchange necessary in modern conditions.

Today the Internet is the main information channel, where news about religious life in Kazakhstan appears and circulates. The Internet is a free environment, practically unrestricted by the ideological and formal framework that operates in the "big media", in addition, other commercial schemes operate here. Therefore, the spectrum of topics artificially narrowed in the modern media mainstream (print media, radio and television), looks much wider here.

\section{Main part}

The most important role played by the Internet in the religious life of Kazakhstan is that this is the only platform for interreligious dialogue at the present day, not at the official level, but at the level of ordinary members of religious organizations and activists. In real life, representatives of different religions and confessions are rare enough to discuss a wide range of issues. On the Internet, they enter the same space. First of all, we are talking about interactive forums and discussing materials on Internet media sites.

Here we turn to the issue of religious and cultural identity in Internet communities. The Internet promotes the transformation of forms of expression of human religiosity. Due to the possibility of participating in various Internet communities, a believer acquires a "second religious identity" - in addition to being a member of a real community, most often - territorial or connected with the circle of his communication, he becomes a member of a community of interests scattered all over the world, in which interpersonal relations are formed, discussions are held on theoretical and religious-social issues.

Often this virtual life becomes more diverse and more in line with the spiritual and intellectual needs of the individual than the real parish community. In the case of Orthodoxy and Catholicism, the virtual community can't replace a person in church services and sacraments, so he is forced to lead a "double" religious life, other religions are more free to perform joint rituals, so, for example, to become a member of the Muslim community or adherent Neo-Protestant and Oriental cults can be, without departing from the computer and never meeting with coreligionists in reality. As a confirmation of this fact, the words of the editor-in-chief of the Independent Islamic Information Channel Islam.ru Rinat Mukhamedov: "Muslims become people by their convictions and sincere belief. On the site, they can leave their data to thereby inform the world of their decision. In addition, there is also a purely religious aspect: according to the Shari' ah, it is desirable that when Muslims are present, two Muslims are present. For someone under current conditions, it is difficult, for example, if a person who wants to become a Muslim lives in an area where there are no followers of Islam or he 
is not yet ready to meet them for some reason" [1]. On the website "Islam.ru" there is a button "I accept Islam", the click of which, according to the authors of the site, is tantamount to publicly pronouncing the formula "There is no God but Allah and Mohammed is His prophet".

Many people satisfy their religious needs, thanks to the Internet, without being in reality associated with a particular religious organization. These people, functioning on the Internet under pseudonyms, consume a "virtual religious surrogate", whereas genuine religious experience can be acquired only by entering into direct communication with spiritually experienced people. Members of virtual online communities can create problems for traditional religious organizations.

In addition, the Internet, thanks to its network structure, creates a breeding ground for various religious and social movements that declare their adherence to one of the traditional religions, but it is often impossible to find out whether their activities are in practice approved by official religious leaders.

There are also a number of difficulties related to the anonymity and pseudonymous anonymity opportunities that the Internet provides. Through the Internet can spread their influence, manipulate society and exert pressure on the power of marginal groups: "A site made by a group of three people and really representing only this group of three people can look much more solid than the site of a large and seemingly large organization. In a sense, this means that it disproportionately represents it, but the power of the public, including the religious group, is only in the strength of its voice" [2]. On television, there is a "picture", a visual series, which serves as an additional source of information about the person or group of people in question. On the radio, this additional source is the voice, intonation, and accent. On the Internet, it is possible to create websites - "Симулярков" and websites - "phantoms" (using the terminology of J. Baudrillard): without knowing the organization or its members in reality, it is often impossible to understand by the Internet representation how authoritative it is and whether it exists in reality. Therefore, on behalf of the "Orthodox (or Muslim, Catholic) public" can act groups that adhere to completely different views and pursuing completely different goals. In addition, a certain topic or phenomenon is often created, which in the virtual world does not correspond to its share in the real world. This is one way to manipulate and change the agenda.

Given the observations of Manuel Castells, that social movements in the information age are mo- bilized around cultural values, the connection of values and mobilization around ideas become necessary, and the way to implement these links and mobilization is primarily the Internet, the development of social movements that have a religious basis and have grown from network communities, seems inevitable [3]. It seems likely that the general shift of these movements towards more radicalism, as the center of social and political discussion in Kaznet shifts towards oppositional radical structures, it is easier to operate on the Internet, hyperbolizing its ideology, because otherwise the virtual communities and individuals become "blurred".

When studying the development of religious communities on the Internet, one can't ignore the fact that from the point of view of the mission, the spread of dogma to traditional institutional religions, the Internet is able to give less than new religious movements. There are even harsh opinions that "for any religious quest outside of institutional religions, the Internet gives a huge advantage. (...) If you want to create a new religion, then the internet will help you a lot, if you want to conduct a mission for old religions with the help of the Internet, this will give you almost nothing. (...) if you construct a quasi-religious or pseudo-religious enterprise, then the Internet is the ideal way for this, where everything like this develops and spreads like viruses "[4]. For "old" religions, the Internet is just another tool for conducting a mission, as the printing press once was, for religious and near-religious movements emerging in the post-industrial era; it is often the only effective means of spreading its ideas. According to the American author David E. Gordon, which he stated in the article "Religion and the Internet," "open access to religious information contributes to the development of religions, which are based not on dogma, but on personal attitudes toward the divine" [5]. The author of the book "The Shine and Poverty of Information Technology" in his article "The Insanity of Web 2.0" also notes the properties of the Internet, favoring the development of beliefs related to the New Age movement, and not institutional religions: "Since its inception, the Web has become a repository of quasi-religious aspirations. Actually, why not? For those who sought transcendental breakdown beyond the material world, the Network is almost ready to land the promised. On the Internet we are all incorporeal - symbols that communicate with symbols through symbols. The early texts on the Metaphysics of the Network (many of them were the people who in one way or another connected with the New Age movement or experienced its influence in the 1960s) are perme- 
ated with a sense of the impending spiritual liberation. The transition to cyberspace is described as a process of personal and social emancipation, a journey that will free us from the traditional limitations of our mind, communities, our physical shell itself. We become "nets" floating freely in some prescient, almost angelic world "[6].

Internet sites - one of the most frequently used means of agitation of religious trends. By placing video and audio sermons, religious figures can fully influence readers. Taking into account the threat of so-called religious extremism for society, the Head of State N.A. Nazarbayev emphasized the increased prevention of religious extremism in society, especially among youth. In this regard, we analyzed the media materials [7]. Despite the fact that Internet sites in the Kazakh language appeared recently, they have already begun to gradually form their audience. Compared to Internet sites in Russian, Kazakh-language Internet sites have a number of features.

First, the audience of users consists of those who quickly mastered the Internet space - usually they are school children and students of higher educational institutions, that is, regular readers of Internet sites are young people $[7,8]$.

Secondly, due to the fact that the Internet is not very common in rural areas, comments on sites in the Kazakh language are written mainly by urban residents. Most of them belong to the layer of Kazakh intelligentsia, thus the audience of users of Kazakh-language sites is limited only by this group. Internet sites become a place for the exchange of views of the national intelligentsia, especially young people.

Thirdly, the content of Internet sites in the Kazakh language is formed by young journalists. If we assume that their basic age in many cases does not reach 30 years, we can conclude that the problems considered on these sites reflect the level of public consciousness of the age group represented.

Fourthly, as online journalism in the Kazakh language is only beginning to develop, the level of web-site technologies compared to sites in Russian is much lower [9].

Hence the content of sites does not reflect national features, and as a result, the level of views of such sites is much lower in comparison with sites in Russian. If you rely on official facts, in Kazakhstan sites in Russian - 32680, in English - 4500, the number of sites in the state language did not even reach the mark of 4 thousand. If you distribute percentages, Internet resources in Russian are $79.6 \%$, in English - 11\%, in Kazakh - 9.3\%. According to some official data, out of 100 websites of the coun- try, constantly working in the Kazakh language, have a good reputation of only 11 , of which information sites are not more than 2-3.

According to statistics, $73 \%$ of Kazakhstan citizens surveyed turn to the Internet for knowledge of religion. This was reported by the head of the Public Foundation "Center for the Study of Terrorism and Extremism in the Republic of Kazakhstan" Kakimzhan Bishmanov at a seminar on countering terrorism and extremism.

"As we expected (getting knowledge about religion) through websites - 73\% (of respondents from Kazakhstan), TV broadcasts - almost 9\%, communication with religious mentors, we say that they listen to sermons and so on - all only $6 \%$, "Bishmanov said [10].

At the same time, he noted that no more than 5\% of respondents receive religious information from books. About $72 \%$ do not believe in the high level of danger of extremist and terrorist organizations in the country, $20 \%$ believe that it is average, and no more than $7 \%$ consider it to be really high. "This indicates the complete carelessness of our population," the expert said.

In his opinion, there is a threat of terrorism in Kazakhstan and it is quite real. As for the issue of personal security, $87 \%$ of respondents are convinced that their personal security is under threat. "From this side they say there is no threat, on the other hand they say that they are very poorly protected," Bishmanov stressed.

About 77\% believe that law enforcement agencies are very poorly prepared for such threats. Most of them consider the formation of an extremist organization as an extremist organization representing various religious movements of a radical nature.

Respondents describe modern terrorists as people who seem to be no different from others. $10 \%$ represent them with large trunks and bags, for $8 \%$ are people in religious clothing. And only 5.3\% believe that a terrorist must have a beard [10].

According to the respondents, the main reason for the emergence and spread of extremism and terrorism in Kazakhstan is the low level of the socio-economic situation in the country. The study involved 500 people, including 72\% Muslims, 9\% professing Christianity, 3\% Buddhists and 15\% atheists. [10]

Religious discussion - by this term we mean a discussion reflected in articles published on websites and affecting the religious norms and concepts of the Kazakh direction of Sufism and Wahhabism. The religious discussion was most of all devoted to 
articles on the sites abay.kz and masa.kz [11]. This is due to the editorial policy of the two sites. It is also noted that the leadership of both sites adhere to the Sufi trend.

The same direction is shared by the members of the editorial board of "Үш қиян" - the Sufis trend. Religious sermons - praising the basic values and norms of Islamic religion on the sites. Religious Literacy - articles on the explanation of the norms and values of the Islamic religion. Many authors believe that the confusion of the religious situation in the country is due to the religious illiteracy of the youth and the lack of information about the basic canons of Islam.

For the period from January 1 to October 10, 2016, the media recorded 1895 materials. Of these, 848 materials were on television, 676 in print media, 371 on news agency websites. Dynamics in terms of months is as follows:

Changes in this spectrum of religious media not only reflect the dynamics of real processes in religious organizations and in society as a whole, but also influence these processes. The impact of the media is modified by the influence of the family, the school, society and other institutions. But we can't ignore the fact that these institutions themselves are also affected by the media. Be that as it may, the study of this phenomenon must be supplemented by an analysis of interpersonal communication, interpersonal relations, taken in all extent and complexity of the whole complex of institutions of socialization and consciousness regulation [12].

\section{Conclusion}

With this analysis, it is found that the media does not and can not provide a mirror of reality. Analyzing the content of religious topics on Kazakh websites, we especially attach importance to their relevance and influence on public opinion. In this connection, before the analysis, the following goals were set: to determine the Internet space for topics in the Kazakh language on religious issues; Identify, the main topics discussed on the sites; To determine the opinion of readers on each topic, based on comments to it.

To select sites used the following criteria: the site size - sites at the national level, site history sites with a history above one year are selected, the site format - only electronic editions are selected, the ranking site of the site - the sites most popular among readers are calculated according to Internet statistics CounterZero [13]. As a result, data have been obtained that allow us to talk about the structure of individual religiosity and correlate, its level with specific psychological characteristics of the individual [14].

Thus, the activation and expansion of the field of EMI activities, the media, the wide use of public opinion polls, religious consultants and specialists engaged in bringing to the broad strata of the population facing the society, positions and alternatives, to increasing opportunities for manipulating people's moods and orientations. In this connection, one more aspect that affects both the religious process itself and its coverage can't be ignored. With the spread of information, the growth of awareness and religious activity has increased [15].

We can draw the following conclusions:

- Traditional or institutional religions are actively using the Internet in their information activities, since it more than other media channels corresponds to the needs and capabilities of religious organizations in the information sphere.

- To a large extent, the presence of traditional religions on the web is limited to "broadcasting" both to the internal and external audience, the interactive potential and the possibility of "feedback" are less involved.

- All traditional religions of Kazakhstan consider the Internet space for the mission and increase their presence in the quantitative and qualitative way.

- The ability of the Internet to create and maintain horizontal social networks, the mobilization of users around common values and interests favor the development and quantitative growth of the religious segment.

The activities of traditional religious organizations on the Internet are complicated by two factors:

a) the fact that the Internet promotes the expression of radical opinions and becomes a breeding ground for extremist movements that position themselves as legitimate representatives of traditional religions.

b) fierce competition from esoteric, pagan and quasi-religious movements (New Age beliefs), the nature of which is more organic than the Internet network organization.

Coordination of religious affairs is the implementation of the religious policy of the spiritual management of Muslims of Kazakhstan and state bodies for religion. Thus, a content analysis of the contents of religious websites was carried out [16]. The features of religious currents in the territory of the Republic of Kazakhstan and the areas of their distribution are analyzed. 